\title{
Subjectivity in Design Education: The Perception of the City through Personal Maps
}

Ebru Yılmaz

\begin{abstract}
Our mental maps related to the cities are limited by our personal perception and fragmented in the process. There are many inner and outer effects that shape our mental maps, and as a result the fragmented whole refers to the total city image in our minds. To represent this image, an experimental study has been conducted with a group of students. They used mapping techniques to design subjective maps. Maps, in general, are objective, and produced by standardised techniques which connote similar meanings for everyone. In contrast, artists and designers use maps as liberating objects of representations. Thus, using mapping techniques, inventing new ways of narration and gaining new understandings towards the city we dwell in are the basic aims of this study. Final designs can be evaluated as tools to question subjectivity in both design and architectural education.
\end{abstract}

\section{KEYWORDS}

maps, subjectivity, city, design, architectural education

\section{Introduction}

The aim of this article is to present a method of exploration for perceiving and comprehending urban space through mapping techniques. Our mental maps of our cities are mostly limited to spaces we live in and our personal perception of urban space is developed in fragments. In order to represent this unity of fragmented images, an experimental work through mapping techniques is conducted by a group of students of architecture. Walking as an urban experience is the starting point of this experimental work. In the text, maps that are generally used as objective instruments of city representations are treated as creative designs which interrogate subjectivity in design education.

\section{Walking and subjectivity in urban space}

Is it possible to consider walking as a means of opening yourself up to the world? As Le Breton states, there is a marvellous world around the walker, because walking is an anthropological activity in terms of understanding one's environment. The walker positions himself or herself in this environment and construes this relationship repeatedly through the activity of walking (Le Breton 2000). Coincidences and possibilities keep the activity of walking alive. Each time the body 
encounters the urban space, it opens up the possibilities of new experiences. In daily life, walking is an emancipating activity where the self uses initiative. It is a method of being, and an association with the universe.

Walking in the modern city and experiencing it is a theme followed by many writers and theorists. By examining the works of Simmel (1903, 1908), Benjamin (1967, 1979, 2006), Debord (2009) and De Certeau (1984), one can find various definitions of the activity of walking and the walker as a figure in the urban space. The distracted urban stroller is traced back to Baudelaire as in the figure of the flâneur and for Benjamin it becomes more visible in nineteenth-century writings. Besides, Simmel formulates the relation of the urban dweller with the urban space in terms of sociological and psychological conditions of the self. For Guy Debord, the walker is conceptualised within the act of drifting whereas de Certeau evaluates this drifter as the ordinary practitioner in the city.

Walking, whether idly or purposefully done, can be evaluated as a heuristic process accompanied by coincidences. Through Benjamin's writings, the flâneur appears as a drifting figure that poetises his urban experience in the city (Benjamin 1967). The flâneur explores the city and goes after his feelings and intuitions idly, like the nature lover who walks freely in the forest. The author states that 'the leisurely quality of these descriptions fits the style of the flâneur who goes botanizing on the asphalt' (Benjamin 2006, 68). The walker makes instant choices. He changes direction, chooses the shortest or the longest way, moves forward by surrendering himself to the enchantment of places. Walking is not simply a physical action any more, but a psychological and subjective activity.

In 'A Berlin Chronicle', Walter Benjamin writes about the guides who introduced him to the city. Beginning from his childhood he discovered the streets of the city under this guidance. As he writes, 'Not to find one's way in a city may well be uninteresting and banal. It requires ignorance - nothing more. But to lose oneself in a city - as one loses oneself in a forest - that calls for a quite different schooling' (Benjamin 1979, 8). For him, getting lost in the city for seeing and discovering is a new kind of experience and walking is a magical activity full of wander. The objects, the built environment, people, signs, sounds, in other words everything that constitute the entire crowd of the city, are natural elements of a magical unity. 'Like the cracking twig under his feet' (Benjamin 1979, 9), the walker is enchanted by the details of the city surrounding him or her. Thus, the city is a place of discovery.

Not only in 'A Berlin Chronicle', but also in his subsequent texts on Moscow, Marseilles, Paris and Naples, Benjamin makes a close 'reading' of cities through his personal experiences and observations like a flâneur (Benjamin 1979). The flâneur, as the walker and the reader at the same time, transforms the meanings of streets, signs, things surrounding him, into new texts in his mind, and he becomes the author of everyday practices of the modern city (Gleber 1999, 52-3). During this activity, Benjamin comes closer to even the smallest detail as he refers to Proust, with an aim that 'now remembrance advances from small to smallest details, from the smallest to the infinitesimal' (Benjamin 1979, 6). He goes in search of hidden meanings and details beyond what is directly seen. At the same time, he oscillates 
between the collective and the individual. The fragments of images of the city perceived through the continuity of vivid memories are not independent from the mental condition of the individual. As Tonkiss remarks, for Benjamin, the city is a collection of individual memories, and this can be the source of numerous stories written on space in everyday life (Tonkiss 2005, 123).

The perception and the narration of the city are interconnected for Benjamin. As a subjective form of writing, he prefers to write with the capital ' $I$ ' in order to present a brilliant narration on space and time (Benjamin 1979, 16). For him, 'memory is not an instrument for exploring the past but its theater', and 'like a man digging' (Benjamin 1979, 26) he digs out his memories for to narrate the city.

Whereas Benjamin directly narrates the city of Berlin through his memories, dreams and childhood perceptions, Simmel analyses the psychology of society. Simmel, in his famous text 'The metropolis and mental life' (1903), discusses the relation between public life and individuality. He defines the psychological foundation of individual in metropolitan life through 'social-technological mechanism' that puts the individual under pressure. 'The intensification of emotional life due to the swift and continuous shift of external and internal stimuli' makes the individual indifferent to his surroundings (Simmel 2005 [1903], 11). While Tonkiss argues on subjective perception in the city, he refers to the 'blasé attitude' of the individual in relation to Simmel's theory. The 'blasé attitude' occurs as 'not seeing and not listening in the city' (Tonkiss 2005, 117). Basically, it designates a condition in which the subjective perception of the city disappears.

Simmel, in the 'Sociology of the senses', drawing on from the individual's relation with the city, proposes that vision is the most powerful way of interaction with the city. He states that

Social life in the large city as compared with the towns shows a great preponderance of occasions to see rather than to hear people... the person who only sees, as contrasted with the one who only hears, brings us to the problems of the emotions of modern life: the lack of orientation in the collective life, the sense of utter lonesomeness, and the feeling that the individual is surrounded on all sides by closed doors. (Simmel 1921 [1908], 146-50)

Simmel makes a correlation between visual perception and the emotional problems of the city dweller. The individual, who mostly observes in the city, is surrounded by the physical and social factors of city life and acquires visual and quick way of interaction with the surrounding. People are confined to their individual shells, and accordingly the communication of the modern individual in the city is mostly limited with the sense of vision. To explain the relationship between modernity and the individual, Gleber states that this individual is a 'medium of perception' who responds to the conditions of the modern city under 'the unexpectedness of violent stimuli', as in Simmel's terms (Gleber 1999, 41).

On the other hand, the mode of seeing and experiencing the city is formulated under two contradictory types by De Certeau. Rooted in 'the totalizing eye' of the 
medieval and Renaissance individual, one is the projection of the technical and theoretical eye and the other is 'the ordinary practitioner of the city' (De Certeau $1984,93)$. These modes of seeing the city indicate that the former is to see the city far from a distance and the latter is to exist in it through bodily experiences. 'Wandersmänner', the walkers, as De Certeau mentions, are both part of the city and the subjects of this experience. To explain this De Certeau continues: 'Wandersmänner, whose bodies follow the thicks and thins of an urban "text" they write without being able to read it. These practitioners make use of spaces that cannot be seen; their knowledge of them is as blind as that of lovers in each other's arms' (De Certeau 1984, 93). For him, the practice of walking is not a totally designed act. Like the lovers, who love each other without being aware of their bodies totally, walking in the city is a condition directed by coincidences without perceiving it under a total consciousness or comprehending the selected route under a holistic fiction. 'The concept-city', 'the hero of modernity' which excluded coincidences of daily life, had once lost its importance for de Certeau. By using the term 'the concept-city', he implies the meaning dictated by design in a rational built environment. However, all individual spatial practices create resistance against suppressing organisations of power (De Certeau 1984, 95-6). Instead of perceiving the city through totalising comprehensions, the individual notices it through daily practices depending on instantaneous choices. At the same time, the movement of the individual in the city cannot be traced, by its very nature. As a result, urban activity based on walking in the city involves infinite numbers of variations and gives way to irrationality.

\section{Psychogeographical maps and practices of mapping}

One of the ways of narrating the city is to present it through maps. For De Certeau, maps slowly evolved from representations of itineraries, tours which are subject-centred, to 'autonomous' representations of Euclidean geometry which are object-centred (De Certeau 1984, 118-22). Consequently, what is a map? A map is by definition 'the representation on paper, etc. of the earth's surface or a part of it, showing countries, oceans, rivers, mountains, etc. (Oxford Dictionary 1974, 519). As a noun, it is a flat diagram of an area of land or sea showing physical features, cities, roads, etc. or a diagram or collection of data showing the spatial arrengement or distribution of something over an area (http://www.oxforddictionaries.com/).

Mostly, maps are taken as 'true' and 'objective' measures of the world. They project a mental, abstract image in our minds through the usage of certain devices such as selection, omission, isolation, distance and codification of things on earth. This image is portrayed in our minds by framing, scaling, orientating, projecting, indexing and naming the existing geographies (Corner 1999, 215). As architects and planners, we conventionally use maps in our projects in order to make an analytical survey of the environment or as a background for the data collection which lets us to develop a design approach.

In addition to the conventional use and production of maps, Corner, in his text 'The agency of mapping', specially elaborates maps not as finished artefacts, but 
as creative activities. He believes that different techniques of mapping may generate new practices of creativity. This speculative idea has triggered the experimental works done in our course. This time, the mapper collects, combines, connects, marks, relates the details, traces, people, buildings or natural objects according to his or her subjective desires. The aim is not to reach an objectively true city map, but subjectively constructed maps of daily life, memories and personally explored places.

For De Certeau, city maps can demonstrate the traces of walking like curves on the map; unfortunately they lack the experience of walking itself (De Certeau 1984, 97). Those abstract points or lines on the map represent the trajectory as a total activity, but on the other hand the whole activity is filled with numerous moments of perceptions, thoughts and reactions. De Certeau clarifies this idea by putting forward a comparison between the 'speech act' and the act of walking. The walker acts in a certain spatial order and creates new possibilities between 'interdictions', just like speech. By doing this, the walker makes choices and individualises his or her experience in the city, which leads to communication and interaction with the environment and other walkers. For De Certeau, like phatic elements of language ensuring communication, walking 'creates a mobile organicity' in the city and consist of 'a sequence of phatic topoi' (De Certeau 1984, 99).

Maps as creative activities, liberating processes, are undertaken by artists in several ways. One of the most powerful references of personal mapping techniques were the Situationists, in the 1960s. As artists and activists, Situationists resembled resisting figures against dominating capitalist powers in the city. They were interested in the situations of everyday life. One of the key figures of the Situationists was Guy Debord, who made a series of maps of Paris, and called them 'psycho-geographic guides' (McDonough 2002, 241-65). These maps did not function like ordinary maps; instead they represented 'atmospheric change' in streets, or 'psychological climates' in the city (Mc Donough, 2002, 245). Debord walked aimlessly in the streets of Paris and recorded his journeys. These subjective maps were a combination of his perceptions and were represented through various artistic techniques like collages of photographs, paintings, texts or newspapers. They emphasised that the city is not a unified whole, but a unity of fragmented perceptions. In his 'Théorie de la dérive' (Theory of the dérive) (1958), the drift was explained as a 'playful-constructive behavior' and should not be confused with 'classical notions of journey', and drifters are aware of 'the attractions of the terrain and the encounters they find there' (Sadler 1999, 77-8). This behaviour should be evaluated apart from habitual acts and let the drifter discover the city idly. As Pinder notes, lain Sinclair is one of those who adopted the Situationists' term 'psychogeography' and walked in order 'to explore and exploit the city' (Pinder 2001, 12). For Sinclair, 'drifting purposefully is the recommended mode, tramping asphalted earth in alert reveries, allowing the fiction of an underlying pattern to reveal itself' (Pinder 2001, 12).

While mapping was, for the Situationists, both an artistic and a political act as a reaction to dominating powers in the city, it is sometimes a personal performance 
for some other artists. Richard Long is one of those artists who works with maps and records his performative act with mapping techniques (Corner 1999, 234). Similar to the Situationists, here the practice of 'drift' itself becomes the map of the artist. In Long's works, the performative activity in a particular distance or a geometrically defined area becomes the map itself. As he explains:

each walk followed my own unique, formal route, for an original reason, which was different from other categories of walking, like travelling. Each walk, though not by definition conceptual, realized a particular idea. Thus walking - as art - provided an ideal means for me to explore relationships between time, distance, geography and measurement. These walks are recorded or described in my work in three ways: in maps, photographs or text works, using whichever form is the most appropriate for each different idea. All these forms feed the imagination; they are the distillation of experience. (Long 2009)

Like Richard Long, Hamish Fulton is an artist who generates his artwork through the experience of individual walks. As a peripatetic individual (Fulton 2012), his thematic walks are the means of engaging with nature. As Cumming states, contrary to Long's works, Fulton does not bring any natural object or material to the gallery or leave any trace where he walks; instead, sometimes he expresses his experience through texts, sketches, structural artworks or film (Cumming 2012).

Similar to the walking and mapping experience of Long and Fulton, Acconci has also used the practice of 'drift'. In addition to his other speculative works, Acconci is an artist, who concerns himself with the idea of viewer and daily life. In his 1969 work 'Blinks', he holds a camera and, while walking a continuous line down the street, takes photos. He says: 'Each time I blink: snap a photo.' In Acconci's work, the New York City is mapped by the photos collected through this process with the practice of 'drift' through an imaginative route (Acconci 1969).

Interactive, continuously changing maps are also created in digital media. Representing maps through the Internet opens up the way of monitoring instantaneously changing personal maps. Aleksandar Janicijevic's internet-based project 'Urbansquares' and Frank Dresme's project named 'Project $360^{\circ}$ ' are all designed in this sense (Janicijevic 2007; Dresme 2007). Similarly, One Block Radius is a webbased project of artists Christina Ray and Dave Mandl in Brooklyn, who are known collaboratively as Glowlab and use the method of mapping in their artworks. They worked on a psychogeographic survey of the building block where New Museum of Contemporary Art of New York was to build a new facility. The aim of work is explained as follows: 'Engaging a variety of tools and media such as blogs, video documentation, maps, field recordings \& interviews, Glowlab creates a multilayered portrait of the block as it has never been seen before [and will never be seen again]. This website is an interactive archive for the project, which will continue to grow over time as we build a dense data-map of the block' (Ray \& Mandl 2004). Like Glowlab, 'Amsterdam RealTime' is another interactive Internet-based mapping project. For the exhibition 'Maps of Amsterdam 1866-2000' at the 
Amsterdam City Archive, Waag Society together with Esther Polak have set up the Amsterdam RealTime project. In believing that every inhabitant has an invisible map of the city, Amsterdam RealTime attempts to visualise these mental maps through examining the mobile behaviour of the city's users (Polak \& Waag Society 2009).

In all these maps, instead of a dominating gaze or an objective representation, personal perception is taken as the starting point of the idea of mapping and the maps all represent the spatial experience of a particular subject, believing that urban space is a collection of individual experiences. For Rendell, encountering spaces in motion while we are walking, 'things seem different depending on whether we are "coming to" or "going from"' (Rendell 2006, 188). This way of perception has a potential for observing and giving meaning to our environment. This potential based on the act of walking can lead to an experimental design practice and be a method for designing. As Rendell states, 'walking proposes a design method that enables one to imagine beyond the present condition without freezing possibility into form' (Rendell 2006, 188). Thus, process of design can be treated as an open-ended, tentative activity full of possibilities. She exemplifies this idea through the works of a group of architects called Stalker (Stalker 2012). As Rendell states, Stalker's projects are based on transgression, thinking and acting in unusual ways. The method that Stalker follows in their projects has three main parts, consisting of first, the collection of information about the site, second, finding a track for walking in the site and, third, documentation of the walk through photographs, texts or films (Rendell 2006, 188). As a result, spatial stories hidden or apparent in urban spaces are narrated and documented through walking experience.

\section{An experiment of mapping}

An experimental study of walking and mapping was conducted in the AR 461 Architecture in Urban Settings course at Izmir Institute of Technology, in Turkey. Within the scope of the course, the research topic for the semester was designated as personal map design. In this context, the course had several aims which are related to the discussion above:

- To create personal consciousness towards the environment in which we live.

- To gain an understanding of the characteristics of the city we live in.

- To critique ourselves and our environment by exploring the concepts of space and place.

- To explore the city by mapping techniques which are powerful in representation.

- To improve techniques for representing subjective narrations and experiences.

- To document local information that is hidden, personal or not apparent.

The main aim of designing personal maps within the content of a course schedule was to bring forward subjective experimentation in design education. Students had both researched the city they live in and designed a map of their own to represent it. Here, the processes of designing and researching are tightly intertwined. Chance, disorder, coincidence and stringing along are the main modes of experi- 
ence that guided both design and research. This approach makes the process of learning dynamic. Even though the students, who are map makers and designers at the same time, walked within the framework of a fiction, they could not entirely predict the final outcome. Some walked in familiar places, and some walked in places where they had never been before. Then, they documented, designed and represented all the data creatively through mapping techniques. At the end of the semester, they shared their final works consecutively with each other, and encountered a fragmented whole of the city which will never be fulfilled.

The students' final works can be gathered under the following topics: Maps of Item Followers, Maps of Trail Hunters, Maps of Memories, Maps of Unfamiliar Places, and Maps as Imaginative Constructs. The topics are imaginative as well as designed products. Each walk experienced by the student is unique in terms of space and time.

\section{Maps of item followers}

Some objects or items in the city are selected as a starting point by students to develop personal maps. Objects or items vary, including pigeons in the city; sounds of public areas; stairs connecting different topographies and territories; flags indicating certain governmental buildings; places selling boyoz as the famous local food of Izmir; the unknown, unnoticeable details in urban space, and so on. Following these items, the students mapped out certain places in the city. According to Benjamin, 'to live means to leave traces' (Benjamin 1979, 146-62). Therefore, by following up traces, chasing details in the city, it is possible to find and expose the city's hidden geographies. In this sense, the work called 'Postcards: details from Izmir' has the aim of communicating with others through details and is designed in the form of a postcard (Figure 1). As Dide Dinç, the designer of this special work, states,

the city is shaped by details, the patterns on your way, the textures you feel, small details that catch your eyes on the streets / on the buildings, you walk on them or pass by, you look around but not that corner! They come together to create the essence of the city you are involved with. Have you ever looked at the city in the way it appears in these postcards?

The cover of 'Postcards' displays a map of the city and the points where the photos are taken. When the locations are visited by the viewer, he or she may be puzzled by the details that they have not noticed before.

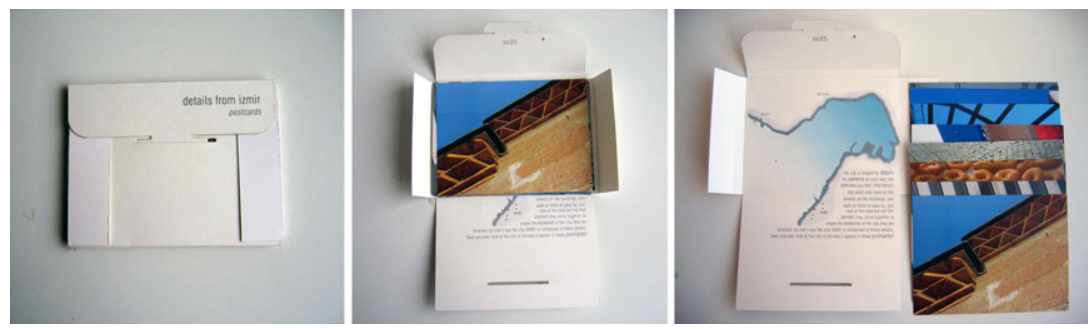

Figure 1. Postcards: details from Izmir, by Dide Dinç 
Another topic for the 'Item Followers' was pigeons in the city. Pigeons, which are excessively involved in urban life, are the subject of this case study. They easily adapt to urban life and look for shelter or a nesting area throughout buildings. Banu Demirel asks questions like 'Why do pigeons live in the city? or 'Where do they live in Izmir?' She narrates her personal map of the city through her tracing of pigeons:

In cities, pigeons form a social network ... Cities provide a habitat for pigeons that closely resemble their natural setting ... They choose places like roof tops and chimneys to live and breed. In cities, people, especially children and tourists, want to see and feed pigeons ... In Izmir, pigeons prefer perching at Konak Square, Uçyol Metro Station, Bornova and Karsiyaka Squares. They perch on top of the cables, trees and lights ... mosques, window frames, chimneys and roof tops of the buildings. There is a nest for pigeons near Uçyol Metro Station.

In urban life, sounds intermingle. Human voices, the sounds of automobiles, buses, mobiles or music, turn the city into a noisy atmosphere. On one hand, it is possible to identify some places in the city with noise, such as bazaars where crowds are intense. On the other hand, urban parks point out leisurely living with silence. Pelin Kurultay traces sounds in the city and tries to design a map of the city through the sounds she hears (Figure 2). She explains that

While we are walking on the street, we don't pay attention to the sounds of spaces. Walking is done either going from one place to another or for sports. And usually we use our mp3 player for listening to music, or chatting with friends or thinking while we are moving. And we miss what the space says.

Pelin's map is designed as a visual, vocal and textual work. Referring to Simmel's sociology of the senses, visual perception is supported by the sense of hearing and makes the viewer focus on the sounds of spaces in Izmir.

\section{Maps of trail hunters}

Some students discovered the city through imagined or constructed routes. Sometimes, the route was designated with an abstract limit, like the number of steps, or sometimes it happened between randomly chosen focal points, which were known or not known. Consequently, they did not know what they would meet when they
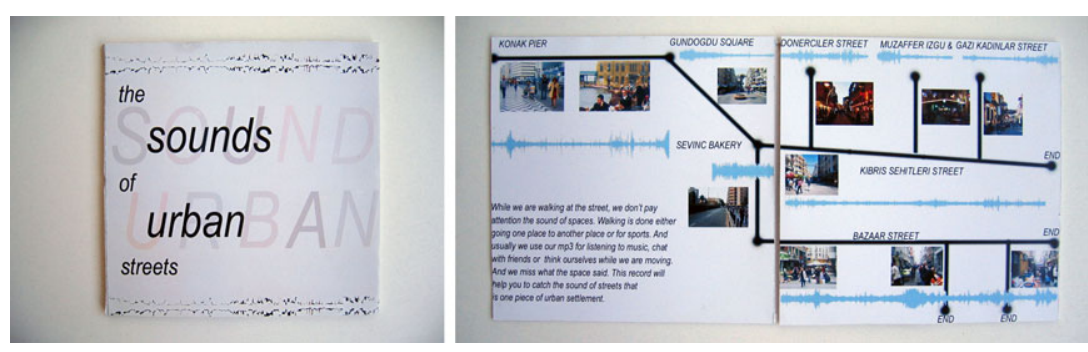

Figure 2. The sounds of urban spaces, by Pelin Kurultay 
turned the corner, walked down the street or finished their walk. Fatma Karaman's walk is one of those thematic walks. She discovered the city in 1,000 steps (Figure 3). In order to reach the end point, she used three different routes, each counting 1,000 steps. She started from Bornova Square and ended up her routes in Ataturk Mahallesi, Kucukpark and Manisa Junction. The one which ended with Ataturk Mahallesi was the most amazing for her. She narrates that

The last point was the most unexpected part of my project. After walking on ordinary, narrow streets, I came up with a great vista of Izmir. Although people living in this district are not so wealthy and live in shanty like houses, every day they enjoy this great vista of the city.

Similar to Fatma Karaman's map, the psychogeographical map of coincidences designed by Ozenc Ozdere and Selcuk Balkan has a certain starting and end point, carried out by two individuals and oriented with coincidences and instant choices (Figures 4 and 5):

'Psychogeographical map of coincidence in Izmir' is a route starting from Konak Square, ending at Alsancak Harbour... Final work is a collage of images exposing physical and psychological characteristics of the walk and is presented in a way of complementing each other.

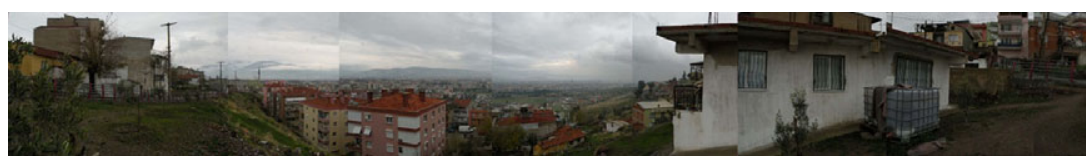

Figure 3. Discovering the city in 1000 steps, by Fatma Karaman

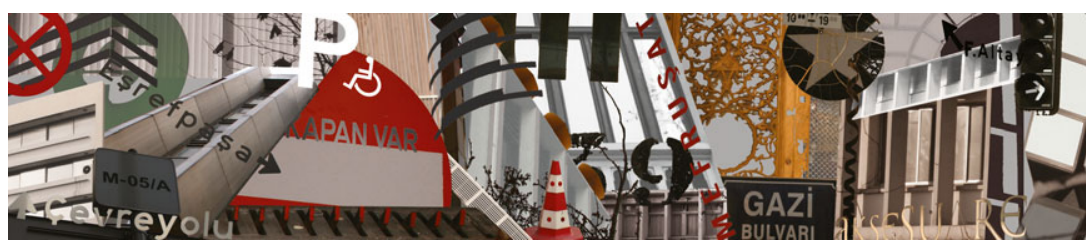

Figure 4. Psychogeographical map of coincidence in İzmir, by Özenç Özdere and Selçuk Balkan

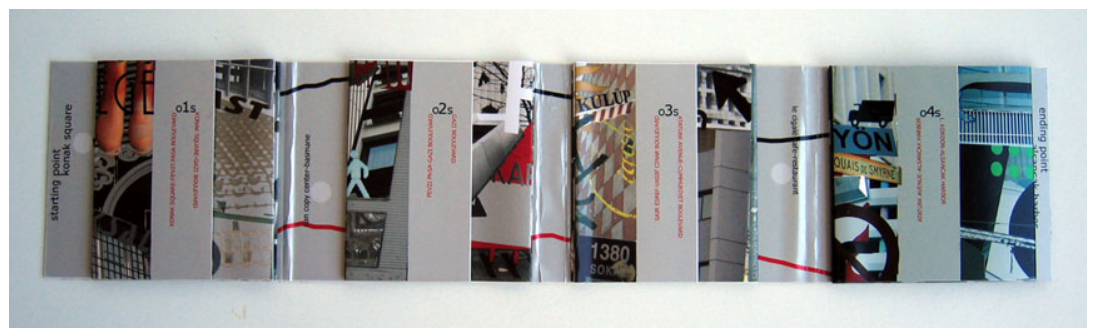

Figure 5. Psychogeographical map of coincidence in İzmir, by Özenç Özdere and Selçuk Balkan 
The complete work is the combination of eight walks and eight collages presented with folded images and texts. At this point, collage is the method used by Ozenc and Selcuk to express the fragmented perception of the city.

Walking has been taken by some of the students as a chance to discover the city without being conditioned. More than focusing on the starting and end points, they focused on the process and thought that 'to lose oneself in the city' was the most magical, enjoyable way of discovering the city. Thus, designs called 'Discovery of getting lost' (Figure 6) and 'Is lost' (Figure 7) are based on this idea.

The design called 'Is lost' has a difference in terms of questioning the idea of getting lost. As Berrin Terim explains:

As an alternative to use a map ... we asked a stranger an address. The reply is usually based on a systematic description. To reach that exact spot, we are told to see or pass some 'exact spots'... After the conversation, we find ourselves in a 'treasure hunt'. In this game, we are no longer hanging out on streets, but we are following the orders of the stranger. To experience this situation, I visited a region in Izmir, a place that I had never been before. One of my close friends who live in Bornova used to mention some place names where she spent her weekends. Instead of using a map, I preferred to ask addresses from the local people of Bornova.

The routes that Berrin used were imaginative constructions of local people. Compared with the other maps, experiencing a place through the experiences of others was the original part of this work.
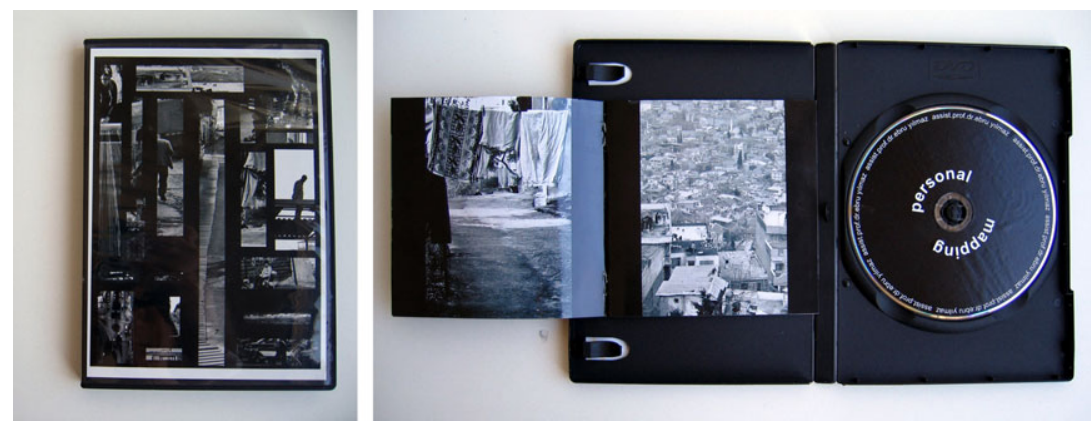

Figure 6. Discovery of getting lost, by Selin Akay

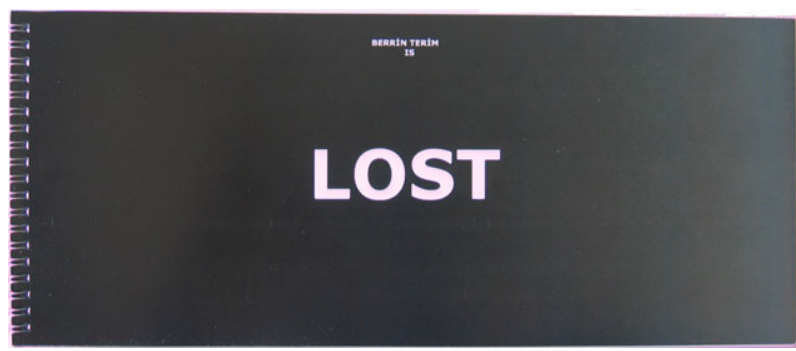

Figure 7. Is lost, by Berrin Terim 
Maps called 'Life on the pavement', by Ayşegül Duran, and 'Pavements', by Özlem Altun, focus on the practices of everyday life in the city and trace details of life on the pavements. Aysegul narrates her walk with a cross-reading of De Certeau's text:

I walked in Izmir. I walked as a walker. While walking, my aim was to see and catch people who are spending time... There was a life on the pavements; there were florists, shoeblacks, lottery sellers, fruit and vegetable sellers, baggers, textiles, etc. Shortly, there was a market on the pavement. Michel de Certeau explains that, a city's layout shows strategies ... on the other hand, the individual walking in the city wanders around aimlessly and 'adopts tactics'.

Similarly, Özlem Altun's route begins from Uckuyular, and continues to the Hatay, Konak and Alsancak districts. Temporary uses on the pavements attract her attention. This is what she calls 'installation city'. Özlem's map is an interpretation of the life on the pavements, this time as an installation in the class. She writes:

For example, near to the major bus station in Konak, vendors' arrangements generate almost a corridor of 'objects' ... Especially in Alsancak, on week days after work hours, pavements are coloured with these 'objects.' ... Street vendors and cafés make this street vivid and colourful...

In this series of works, Pinar Bingol's map illustrates the route of ecological places in the city (Figure 8). Essentially, an ecological walk resembles a quiet walk which tries to keep away from traffic, air pollution, noise and crowds in the city. The walk focuses on parks and green areas in Buca. Pınar's narration of her ecological walk swings between historical information and personal memories and experiences. She explains:

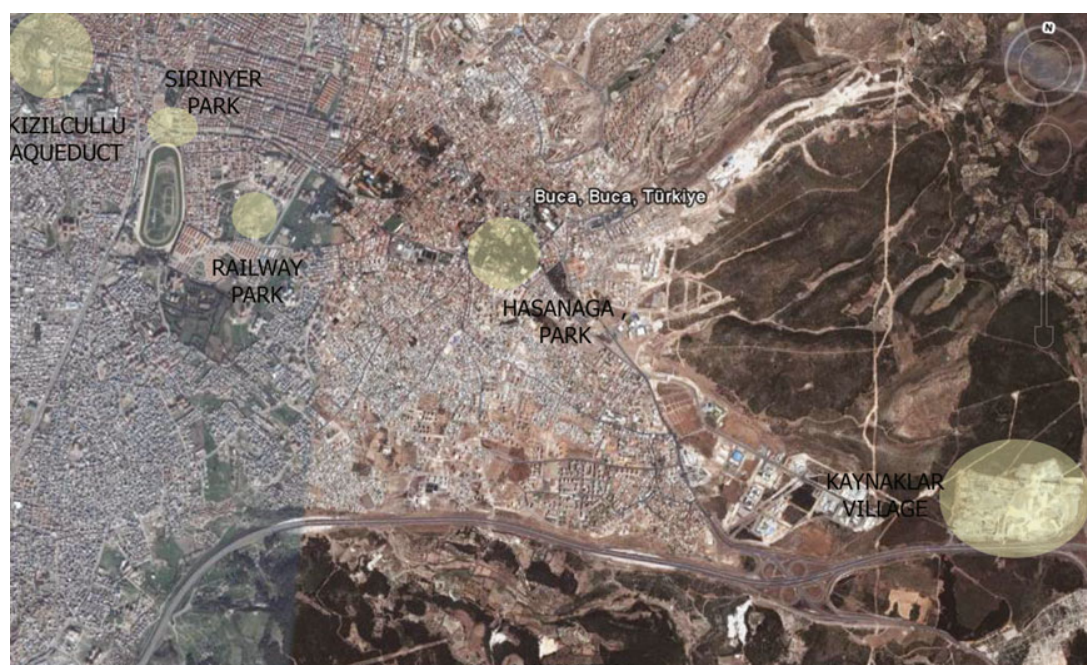

Figure 8. Ecological walk, by Pınar Bingöl 
Kızılçullu Aqueduct resembles the entrance of Buca ... Firstly, in the Roman period, the aqueducts carried water into the city ... Secondly; children who grow up in Şirinyer certainly spend a period of their life in Sirinyer Park where you can find a bazaar, small hills, playground and benches ... Then thirdly, Hasanağa Park was the garden of an Italian businessman's house ... Generally, there are pines and mulberries which took a special labour to grow. There was a small zoo before, but now only birds are living ... And finally; Kaynaklar Village ... The village takes its name due to the of spring water. The place is also popular with its plane trees which are nearly 100 years old. People come here for climbing and camping activities.

\section{Maps of memories}

Walking is an activity that allows us not only to think of ourselves and our environment, but also our past memories. Thus, while walking we see things that do not exist as well as those that do. Walking in the city and tracing our memories is narrated by Benjamin in detail. In this sense, some of the maps designed by students display their personal spaces of memories in the city, like places they used to go, places of their childhood, places that remind the memories of others.

In our daily life, we remember our memories in relation to objects or people we encounter. This does not occur in a linear process: the image of places in our minds arise within an overlapping process of memories. Ebru Betuz's work in a sense is a representation of this process (Figure 9). She concentrates on her memory points of Izmir, and tries to design a map of this fragile imagination. Transparent layers of pages pointing out places which have strong influence in her mind are written down together with the names of places and objects. In Ebru's work, memories and places are highly abstracted and represented in minimalist understanding.

In this series of maps, Seval Erdem's map projects special treatment (Figure 10). A map that is designed as a three-dimensional model consists of three layers which refer to three different kinds of abstraction. Seval explains her idea of layering in her narration:

First layer is a hidden one and consists of small texts written about places I have visited. On the second layer, you can find the photographs of these particular places and a formal city map displaying all the street and district names. And finally, the third transparent layer on the top displays the names of the streets, particular corners, or buildings which I renamed through my imagination. The imaginative names, the real, and my thoughts of those places are all superimposed in this $50 \times 50 \mathrm{~cm}$ model.

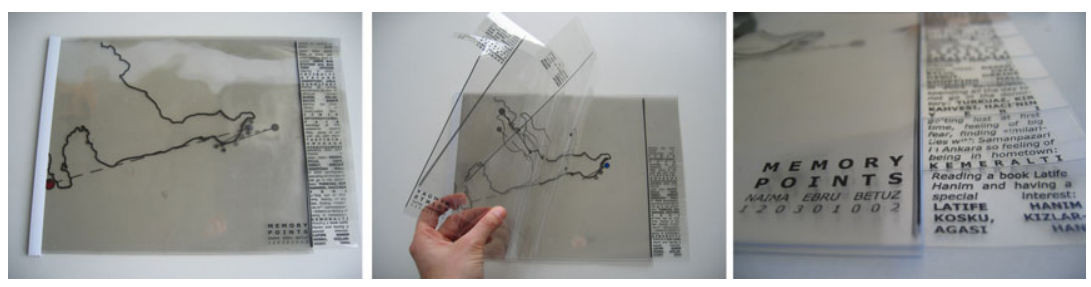

Figure 9. Memory points, by Ebru Betuz 


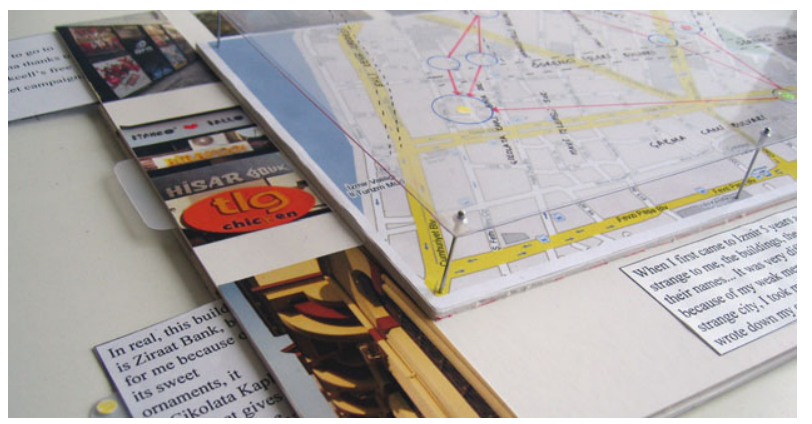

Figure 10. Street names of my memories, by Seval Erdem

The viewer is free to flow among these layers. Photos and texts are designed as changeable elements that construct the map and support imaginative and real dimensions of it. The success of Seval's map lies first in its materiality and secondly in the imaginative construct of memories through this layering system.

Duygu Kalkan's city map also focuses on hidden details, and it explains them through memories of people and histories of certain places (Figure 11). She comments on her city map as follows

this is an album of my mental world, of things that affect me, and are forgotten in the city ... This album-like map is inspired from an old album found in an old mansion in Basmane dating from the 1930s. This memory box displays some particular details hidden in Konak, Kemeraltı, Alsancak and Çankaya districts and explains their short history.

Integrating personal memories with the history of places is the basic idea that generates these maps. In the case of Duygu Kalkan, the design of her map stems from a photo album found in one of the walked areas, and this accidental situation makes the closed black box full of wonder for the viewer.

\section{Maps of unfamiliar places}

The main aim of the group of students in this part was to design a map that showed a district which they had not visited before. The starting point for the walking route was either a well-known place or an unknown part of the city. Walking around unfamiliar places was a real activity of exploration for them. Strangeness is the common feeling that triggers the mappers. For instance, Izmir's ancient
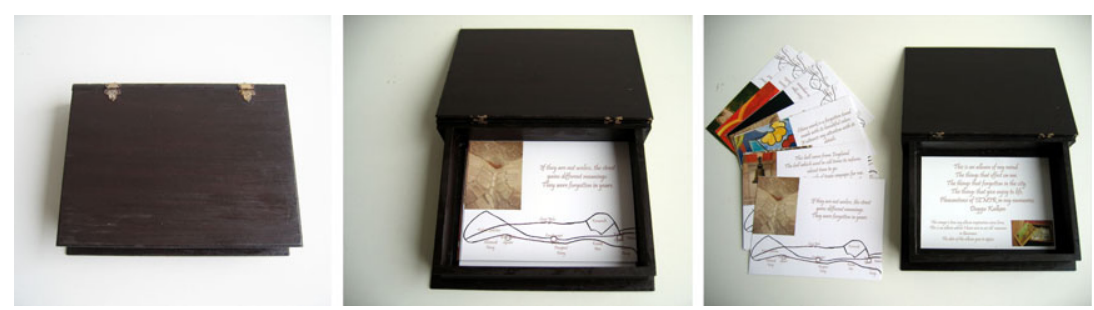

Figure 11. İzmir in my memories, by Duygu Kalkan 
marketplace called 'Agora' is mostly in ruins and it cannot integrate with the daily activities of citizens. Old squatter houses surrounding the area create an uncanny sense of feeling for the visitor. While Belkis Dönmez tries to learn about the historical background of the area, excavations are still being carried out (Figure 12).

On the other hand, Özge Açık walked through unfamiliar and hidden places in the city, but contrarily looking out for a sense of tranquillity (Figure 13). She escaped from the crowds of the city and followed the traces of silent and isolated places that attracted her attention.

\section{Maps as imaginative constructs}

For some of the students, the idea of making a map occurred as an imaginative construction. For this reason, the map itself became a game, a calendar or an interactive web site. Here, the map functions as a background for the main idea. Jozef Madej designed a game and series of maps together, first to present an enjoyable interface for the viewer and second to introduce Izmir city to a stranger (Figure 14). He simply explains the rules of the game:
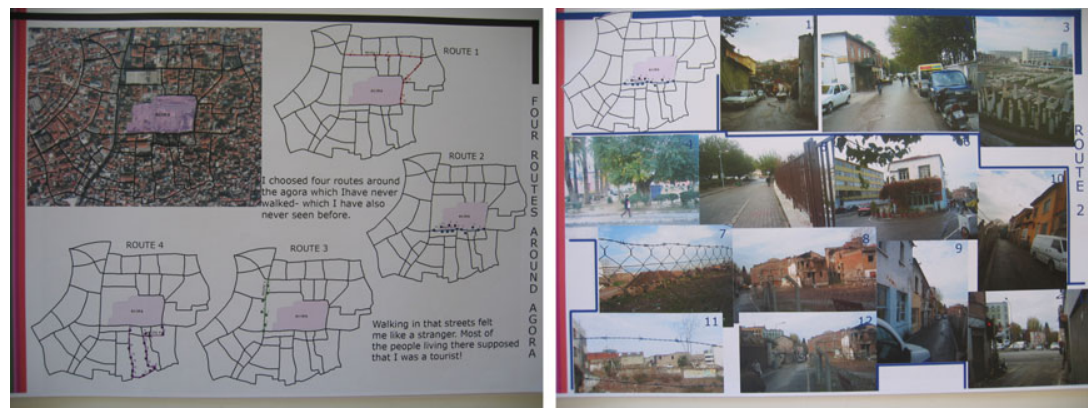

Figure 12. Walking in Agora, by Belkıs Dönmez

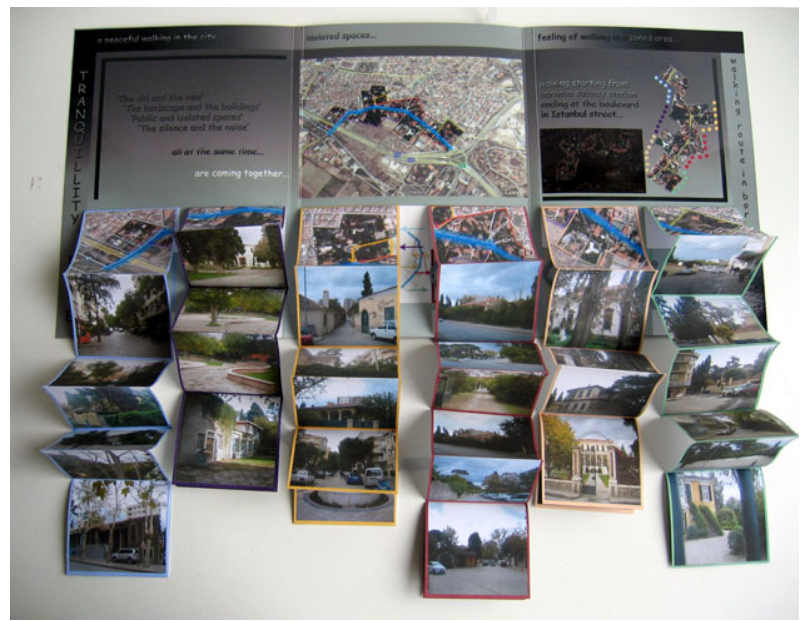

Figure 13. Discovery of hidden spaces, by Özge Açık 


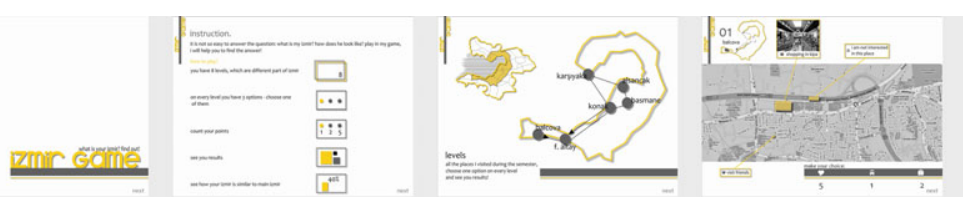

Figure 14. İmir game, by Jozef Madej

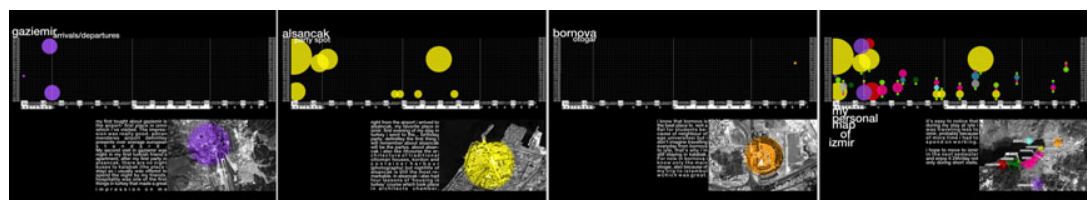

Figure 15. My personal map of Izmir, by Krzysztof Czech

What is your Izmir? Let's find out! There are eight levels, which represent different parts of Izmir, and there are three options on each level. Each time you make your choice, you count points, at the end according to the points you collect, you can learn what type is your Izmir and how it relates to the existing one.

According to Jozef's game, Izmir in your imagination may be a mixture of places of entertainment, culture, commerce and so on. He makes a correlation between personal analysis and urban spaces and asserts that an individual's personal characteristics originate his or her imagination of the city.

As a short-term visitor in Izmir, Krzysztof Czech designed his map as a calendar (Figure 15). The map displays visited places, dates, times and locations. He notes his personal impressions of four months' stay in Izmir in addition to notations on the map. The process of getting to know a city and Krzysztof's personal history ironically overlap with a map design.

\section{Research and design}

In this study, maps are not the result of objective perception, but they are the final products of subjective perception, experiences of walking, seeing, documenting and the process of designing. The instructor's role is only to guide the students' discovery process, and be an intermediator of sharing and discussing subjective experiences with the others. By referring to Schön and experimental processes of design, what O'Neill maintains is that the instructor 'loses authority and expertise over these individualized explorations' (O'Neill 2001, 11). This study involves a process in which the instructor voluntarily chooses to lose her authority. This is because the methods used for understanding urban space through subjective practices such as the walking activity, and finally developing creative methods to represent it, totally refers to an emancipatory process.

Graeme Sullivan states that 'rather than seeing inquiry as linear procedure or an enclosing process, research acts can also be interactive and reflexive whereby imaginative insight is constructed from creative and critical practice' and continues 
that this type of arts-based research suits art practitioners, artists, teachers or students (Sullivan 2006, 20). The idea proposed can be adapted to the creative processes of design education. Creative and design-based processes can be developed so as to improve our insight about learning and teaching in design education. Sullivan explains arts-based educational inquiry as a descriptive and interpretive phenomena through 'seeing' and 'sensing' (Sullivan 2006, 23). These features of research suggest subjectivity and experience in terms of both observation and representation, and comply with interdisciplinary approaches.

For Donald Schön, 'epistemology of practice implicit in the artistic and intuitive processes', which defines an alternative situation against positivist epistemology, can open up the way of 'learning by doing' (Schön 1983, 31). He states that design education is basically appropriate for reflective communication which enhances the exchange of ideas (Schön 1983, 54). I would like to interpret this approach in a different way. Reflective conversation between the student and the tutor, which is closely examined by Schön, can vary in several ways. Sometimes it is not only the instructor who participates in 'reflective conversation', but also the environment or outer agents. Similarly, the students who worked on personal maps tried to discover new ways of 'reflection-in-action', which involve the process of experimenting (Schön 1983, 141). In addition to the process of discovering urban space in a reflected manner, personal narrations in representations also differ in terms of educational practice. In objective education personalities are mostly hidden, but in these works the final design as a map is personally narrated by each student and is firmly based on his or her subjectivity.

\section{Conclusion}

As Elizabeth Wilson states, we should respond to cities as we respond to 'nature or dreams: as objects of exploration, investigation and interpretation, setting for voyages of discovery' (Wilson 1991, 11). The students showed the courage to go after their place of memories, places they did not know, or places of forgotten details. In order to design their own map, they walked around the city. In these walking activities, they recorded, documented and finally designed a map. The success of the course work can be evaluated under two main topics. First, a piece of research itself can become a design product. The idea of mapping and mapping techniques offers a very useful ground for this approach. Secondly, subjective perceptions are powerful ways to apprehend the meaning of urban space.

Ebru Yılmaz is an Assistant Professor in the Faculty of Architecture at Izmir Institute of Technology, IYTE. She received her Bachelor (1995) degree in Architecture at Dokuz Eylül University in İzmir. She obtained her Master's (1998) and doctorate (2004) degrees at iYTE., in the Department of Architecture. Her doctoral dissertation was entitled 'Determination of Place Concept in the Reproduction Process of Built Environment: Kordon, Izmir as a Case Study'. She has received awards in architectural competitions. She currently teaches undergraduate and graduate programmes. Contact address: Izmir Institute of Technology, Architecture, Gulbahce Koyu Urla, Izmir 35430, Turkey. Email: ebruyilmaz@iyte.edu.tr 


\section{References}

Acconci, V. (1969) Blinks (online). Available at: http://aleph-arts.org/art/lsa/lsa39/eng/ 1969.htm (accessed 15 June 2012)

Benjamin, W. (1967) Der Flaneur, Neue Rundschau, Vol. 78, No. 4, pp. 549-74.

Benjamin, W. (1979) Reflections, Essays, Aphorisms, Autobiographical Writings. New York and London: Harvest/HBJ.

Benjamin, W. (2006) The Writer of Modern Life: Essays on Charles Baudelaire, Michael W. Jennings [Ed.], Howard Eiland, Edmund Jephcott, Rodney Livingston and Harry Zohn [Trans.]. Cambridge, MA and London: Belknap Press of Harvard University Press

Corner, J. (1999) The agency of mapping: speculation, critique and invention, in D. Cosgrove [Ed.] Mappings. London: Reaktion Books, pp. 213-52

Cumming, L. (2012) Hamish Fulton: Walk; Turner and the Elements - review (online). Available at: http://www.guardian.co.uk/artanddesign/2012/jan/29/hamish-fulton-walkturner-margate-review (accessed 15 June 2012)

Debord, G. (2009) Correspondance, The Foundation of the Situationist International (June 1957-August 1969). Los Angeles: Semiotext(e).

De Certeau, M. (1984) The Practice of Everyday Life. Berkeley: University of California Press.

Dresme, F. (2007) Project $360^{\circ}$ (online). Available at: http://www.21 bis.nl/project/26/12 (accessed 15 June 2012)

Fulton, H. (2012) Works (online). Available at http://www.hamish-fulton.com (accessed 15 June 2012)

Gleber, A. (1999) The Art of Taking a Walk: Flanerie, Literature, and Film in Weimar Culture. Princeton: Princeton University Press.

Janicijevic, A. (2007) Urbansquares (online). Available at: http://www.urbansquares.com (accessed 15 June 2012)

Le Breton, D. (2000) Eloge de la Marche. Paris: Editions Méttailié.

Long, R. (2009) Heaven and Earth (online). Available at: http://www.richardlong.org/ and http://www.tate.org.uk/whats-on/tate-britain/exhibition/richard-long-heaven-and-earth (accessed 15 June 2012)

Mc Donough, T. (2002) Situationist space, in T. Mc Donough [Ed.] Guy Debord and the Situationist International: Texts and Documents. Cambridge, MA: MIT Press, pp. 241-67

O'Neill, M. E. (2001) Corporeal experience: a haptic way of knowing, Journal of Architectural Education, Vol. 55, No. 1, pp. 3-12.

Pinder, D. (2001) Ghostly footsteps: voices, memories and walks in the city, Ecumene, Vol. 8, No. 1, pp. 1-19.

Polak, E. \& Waag Society (2009) Amsterdam Real Time (online). Available at: http:// project.waag.org/realtime/ (accessed 15 June 2012)

Ray, C. \& Mandl, D. (2004) One Block Radius (online). Available at: http://glowlab.blogs. com/psygeocon/2004/02/participant_23.html (accessed 15 June 2012)

Rendell, J. (2006) Art and Architecture: A Place Between. London: I. B. Tauris.

Sadler, S. (1999) The Situationist City. Cambridge, MA: MIT Press.

Schön, D. A. (1983) The Reflective Practitioner: How Professionals Think in Action. New York: Basic Books.

Simmel, G. (1921 [1908]) Sociology of the senses: visual interaction, in R. E. Park \& E. W. Burgess [Eds] Introduction to the Science of Sociology, 3rd edn. Chicago, IL: University of Chicago Press, pp. 356-61.

Simmel, G. (2005 [1903]) The metropolis and the mental life, in Gary Bridge and Sophie Watson [Eds] The Blackwell City Reader. Oxford: Blackwell, pp. 11-19. 
Stalker (2012) Manifesto (online). Available at: http://digilander.libero.it/stalkerlab/tarkowsky/ manifesto/manifesting.htm and http://www.osservatorionomade.net/ (accessed 15 June 2012)

Sullivan, G. (2006) Research acts in art practice, Studies in Art Education, Vol. 48, No. 1, pp. 19-35.

Tonkiss, F. (2005) Space, the City and Social Theory: Social Relations and Urban Forms. Cambridge: Polity Press.

Wilson, E. (1991) The Sphinx in the City: Urban Life, the Control of Disorder, and Women. London: Virago. 